\title{
Preparing Modified Bonding Representations Inventory: Challenges and Solution
}

\author{
Pinaki Chowdhury ${ }^{*}$ (iD \\ ${ }^{1}$ Tshwane University of Technology, South Africa \\ *Corresponding author: pinakichowdhury@yahoo.com
}

Abstrak

Mengumpulkan data tentang kinerja peserta didik dalam konten kimia yang berbeda dan menganalisisnya untuk mengidentifikasi pengetahuan dan pemahaman mereka di bidang konten terkait adalah tugas utama Penelitian Pendidikan Kimia. Proses pengumpulan data pengetahuan konten peserta didik dan pemahaman konten pengetahuan memerlukan alat ukur standar. Penyusunan alat standar untuk mengukur prestasi akademik membutuhkan perangkat lunak komputer. Semua perangkat lunak yang digunakan dalam standarisasi alat dikenakan biaya dan memerlukan pelatihan bagi peneliti yang terlibat dalam menangani situasi, yang dapat menghambat kelancaran proyek. Hal yang sama terjadi ketika penulis sedang mengerjakan modifikasi inventaris representasi ikatan (BRI) untuk penggunaan lokal di Afrika Selatan. Laboratorium analisis data terletak di kota yang berbeda, $500 \mathrm{~km}$ dari tempat kerja peneliti. Karena jarak yang jauh dan keterlambatan komunikasi, penulis prihatin dengan keterlambatan proyek. Diketahui bahwa kebutuhan, yang dapat menciptakan peluang. Platform Microsoft Excel (MS-Excel) digunakan untuk standarisasi BRI yang dimodifikasi karena MS-Excel tersedia sebagai standar di MS-Office pada platform Windows. Makalah ini menyajikan sebuah fakta. Itu, sebuah alat dapat distandarisasi dengan menggunakan MS-Excel tanpa kerumitan apapun.

Kata kunci: Standarisasi Inventarisasi, Inventarisasi Representasi Ikatan Termodifikasi, Penelitian Pendidikan Kimia, Tabel Periodik dan Ikatan Ion

\section{Abstract}

Collecting data on learners' performance in different chemistry contents and analysing them to identify their knowledge and understanding in related content areas is a major task of Chemistry Education Research. The data collection process on the learners' content knowledge and understanding of content knowledge requires a standard measuring tool. The preparation of standardized tools for measuring academic achievement requires computer software. All software used in the standardization of a tool comes at a cost and requires training for the researcher involved in handling the situation, which can impede the smooth running of a project. The same was the situation when the author was working on modifying the bonding representations inventory (BRI) for its local use in South Africa. The data analysis laboratory was situated in a different city, $500 \mathrm{~km}$ away from the researcher's field of work. Owing to the long distance and communication delay, the author was concerned with delays in the project. It is known that necessity, which can create an opportunity. The Microsoft Excel (MS-Excel) platform was used for standardizing the modified BRI because MS-Excel is available as a standard in MS-Office on the Windows platform. This paper presents a fact. That, a tool can be standardized by using MS-Excel without any complexity.

Keywords: Standardization of Inventory, Modified Bonding Representation Inventory, Chemistry Education Research

\begin{tabular}{ll}
\hline History: & Publisher: Undiksha Press \\
Received : August 03, 2021 & Licensed: This work is licensed under \\
Revised : August 06, 2021 & a Creative Commons Attribution 3.0 License \\
Accepted : September 12, 2021 &
\end{tabular}

\section{INTRODUCTION}

High school learners' and undergraduate students' difficulties in understanding different chemistry concepts and the presence of alternate concepts have been well reported (Nyachwaya et al., 2011; Suat et al., 2010; Taber, 2011). In each and every case, scholars used different inventories of their choice to identify the learning difficulties and misconceptions of the students involved in their studies. For example, the Melting Cycle Instrument and Dissolving Cycle Instrument were used to identify the general misconceptions of chemistry students on the particle position during the reversible physical change of melting and dissolution (Smith \& Villarreal, 2015). Researchers also suggested that identifying 
students' misconceptions and the source of such misconceptions could play an important role in improving the learning outcomes in chemistry (Tümay, 2016). Inventories are extensively used in Chemistry Education Research studies to determine the status of the chemistry teaching-learning outcomes along with the learners learning difficulties. A part of the author's doctoral study (2018-2019) identified the high school learners' level of knowledge and understanding of the periodic table, atoms, and ionic bonding. While searching for an inventory, researchers from the USA used bonding representations inventory (BRI) (Luxford $\&$ Bretz, 2013). The same inventory was also successfully used by researchers in Slovak schools (Vrabec \& Prokša, 2016). The researchers from the USA agreed to assist the author by giving permission to use the BRI that was developed in the USA and used by their team both in the USA and Slovakia. The original BRI was developed by researchers to study students' level of knowledge and understanding of ionic and covalent bonding.

Original BRI had ten test items relating to covalent bonding; hence, these ten test items were removed from the inventory before moderating the original BRI for the proposed study. There were 23 continuous test items in the original BRI without any groupings, of which ten test items were already removed. The original BRI included; the following: (i) Periodic Trends, (ii) Electrostatic interactions, (iii) The Octet rule, and (iv) Surface Features. The author was looking for a tool to study the learners' knowledge and understanding of the periodic table, atoms, molecules, and bonding (ionic only). A set of new test items were introduced to include the contents from the periodic table. This was conducted in consultation with local subject experts. These experts comprised high school chemistry teachers, science department heads, chemistry subject specialists, and university faculties from science education. Finally, the BRI was modified. Twenty-four new test items were added to the BRI. Consequently, the modified BRI constituted of the 37 test items in total and was grouped into four sections (A, B, C, and D).

Therefore, modified BRI was empowered to determine learners' state of learning about the periodic table, atoms, molecules, and ionic bonding. The author considered these forms fundamental component of high school chemistry courses and responsible for developing many alternate concepts carried by learners to their higher grades. The study prepared a standard, modified bonding representations inventory (Modified BRI). The objective of the study was to establish the validity and reliability of the modified BRI. Learning of humans occurs via three main interactive processes cognitive, experiential, and socio-cultural interactions (Jarvis, 2012). Every learning process involves the mind and intellect of a person. The author suggests that all human thought processes work in the same direction when common scientific content is handled by different individuals to uncover it and develop an understanding. In the process they either pick up the correct concept that needs to be developed in the mind or an alternate concept which hinders further learning of the appropriate scientific content. This fundamental is used here as a background to the need of developing a testing inventory in a content area of chemistry called the Periodic Table and Ionic Bonding.

A concept inventory is developed from interview analysis and a literature search on previously known misconceptions, capturing expert knowledge on those ideas, and questions were developed to measure that knowledge (Krause et al., 2004; Pellegrino et al., 2001). Researchers' from the USA interviewed several American students' to identify their understanding of, and misconceptions about, covalent and ionic bonding representations through an analysis of both student-created and expert-generated representations. These directed them to develop the BRI based on the students' misconceptions (Luxford \& Bretz, 2013). The same inventory was also used successfully in Slovakia (Vrabec \& Prokša, 2016). The author used the already developed inventory called the BRI prepared with due diligence. However, the author modified it according to its local requirement. 


\section{METHODS}

One of the most important aspects of any inventory is its validity. The validity of a study depends on the validity of the tool used to collect data for the study under consideration. The validity determines if the research or a research tool truly measures what it was intended to measure (Golafshani, 2003). Different researchers identified and expressed the validity in different ways and called them as follows: face validity (Hardesty \& Bearden, 2004), construct validity (Cronbach \& Meehl, 1955), criterion validity (Beekman et al., 1997), formative validity (Crooks, 2001), and sampling validity (Kane, 1982). This study prepared an inventory to be valid for testing learners' knowledge and understandings about the periodic table, atoms, molecules, and ionic bonding that are taught at the high school physical science curriculum of South Africa. An original copy of the BRI was obtained from researchers (Luxford \& Bretz, 2013). The BRI was then restructured by the author and sent to different subject experts for their comments and suggestions. The experts included chemistry teachers from schools, heads of departments from different schools, subject advisors, school principals, and faculty members from university who were dealing in the contents of chemistry. The author then analysed feedback from each of the subject experts. Each of the question statements was scrutinized independently for their content validity and they were then divided into the following categories: knowledge, understanding, application, and mind reading. The mind-reading part of the test items was intended to identify the learners' actual thinking about the content, which identifies alternate concepts of each individual learner that were developed in the selected content areas.

In short, mind reading refers to identifying the learners' actual idea about the content matters. The test items were then grouped according to their content coverage. The face validity and content validity of the modified BRI were thus established. The inventory was then administered among conveniently selected grade ten and grade eleven learners from local high schools. The responses of the participating learners were then coded and captured for further analysis. First, the collected data used for the test-retest reliability test using two different groups belonging to the same grade but from different schools. Next, internal consistency of the testing instrument means that the construct validity was established by measuring the alpha value from the entire data collected. The sample for the study was selected based on the convenient selection and willingness of the participants from a local municipal area in the Mpumalanga province of South Africa. Two schools from Nkomazi Municipal area were selected conveniently, where the school administrators agreed to assist in implementing the test after discussing it with their learners. Forty-one grade eleven and 39 grade ten learners were selected randomly for the study by the school administrators based on the willingness of the learners to take the test in December 2018. In another school (January 2019) 39 grade eleven learners were administered the test based on their willingness. The author also administered the test to one undergraduate student. At its second stage 31 learners from grade ten were also selected for a test -retest reliability test from a different school.

\section{RESULTS AND DISCUSSION}

\section{Results}

The tool under consideration had four sections embedded in it. Section A contained question on the periodic table. Sections B and C, had questions regarding atoms and molecules. On the other hand, section $\mathrm{D}$ was based on ionic bonding. The developed inventory used three types of test items. Memory based, to determine the learners' knowledge on the given content areas; application and understanding-based questions, and distractors to determine the students' alternate concepts (mind -reading of learners). Table 1 and Table 2 explain detailed structuring of the modified BRI. 
Table 1. Number of Questions \& Content Covered in Each Section

\begin{tabular}{|c|c|c|c|c|c|}
\hline Section & $\begin{array}{c}\text { Total } \\
\text { Questions }\end{array}$ & Content & $\begin{array}{c}\text { Memory } \\
\text { Based } \\
\text { (Knowledge) }\end{array}$ & $\begin{array}{c}\text { Application \& } \\
\text { Understanding } \\
\text { Based }\end{array}$ & $\begin{array}{c}\text { Mind } \\
\text { Reading I.E. } \\
\text { Logic of } \\
\text { Answering }\end{array}$ \\
\hline $\mathrm{A}$ & 4 & Periodic Table & 2 & 2 & \\
\hline B & 8 & $\begin{array}{l}\text { Elements \& } \\
\text { Compounds }\end{array}$ & 1 & 3 & 4 \\
\hline $\mathrm{C}$ & 8 & $\begin{array}{l}\text { Elements \& } \\
\text { Compounds }\end{array}$ & 7 & 1 & \\
\hline $\mathrm{D}$ & 17 & Ionic Bonding & 5 & 4 & 8 \\
\hline
\end{tabular}

Table 2. Question Number and Its Type

\begin{tabular}{lllll}
\hline Section & & Knowledge & $\begin{array}{l}\text { Application \& } \\
\text { Understanding }\end{array}$ & Distractor \\
\hline A & Question Numbers & 3,4 & 1,2 & Nil \\
B & Question Numbers & 7 & $1,3,5$ & $2,4,6,8$ \\
C & Question Numbers & $1,2,3,5,6,7,8$ & 4 & Nil \\
D & Question Numbers & $1,5,12,14,16$ & $3,7,8,10$ & $2,4,6,9,11$, \\
& & & & $13,15,17$ \\
\hline Total $(\mathbf{N})$ & Questions & $\mathbf{1 5}$ & $\mathbf{1 0}$ & $\mathbf{1 2}$ \\
\hline
\end{tabular}

There were fifteen knowledge -based questions, ten questions to determine the understanding level, and twelve distractors to identify alternate concepts or misconceptions of the participating learners. Therefore, there were total thirty -seven questions in the inventory. For this study, two schools in the Nkomazi Municipality area under Mpumalanga province of South Africa were selected conveniently a private school from an urban area and a public school from a semi -urban area. The criteria for selecting the public school was its status as a member of the Mathematics Science and Technology Academy. The test was administered to one grade ten and two grade eleven classes of learners from the selected schools. One undergraduate student studying chemistry in year one also wrote the test.

The test scores were captured using the exact response number (scale/question numbers here) copied in the score sheet as indicated in the tool in an excel program sheet. A score of eight was used for a non-relevant response. On the other hand, a score of nine was awarded for a space left blank by a learner. Clarification for a non-relevant answer is required for the readers. The learners were provided with a response sheet. The learners were supposed to copy the symbol of their choice over the response sheet. Some responses written on the response sheet did not match with the choices given in the test items. In such cases, a score of eight was used. Test Score also using a binary system, 0 for an incorrect response and 1 for a correct response. A list was prepared to indicate the number of students scoring zero and leaving a blank under each group (presented in Table 3). Neither a floor effect (a large number of students scoring zero) nor a ceiling effect (a large number of students with a perfect score) was observed. The next task was to determine the reliability of the modified BRI in terms of its measuring skill. A testing instrument was considered reliable if the standard error of its every test item was zero or close to zero. The standard error for each test was calculated from the learners' choice of correct and incorrect responses (collected in 0 and 1 format) Figure 1 presents a graph of standard error values. 
Table 3. Number of Students Scoring Zero or Keeping a Blank

\begin{tabular}{llllll}
\hline Grade & $\begin{array}{l}\text { Total } \\
\text { Number }\end{array}$ & Section A & Section B & Section C & Section D \\
\hline 10 & 39 & $\mathrm{X}$ & 1 & X blank 1 & 1 blank 2 \\
11 & 80 & 25 & 1 & 1 blank 1 & 7 blank 2 \\
UG & 1 & 1 & X & X & X \\
\hline
\end{tabular}

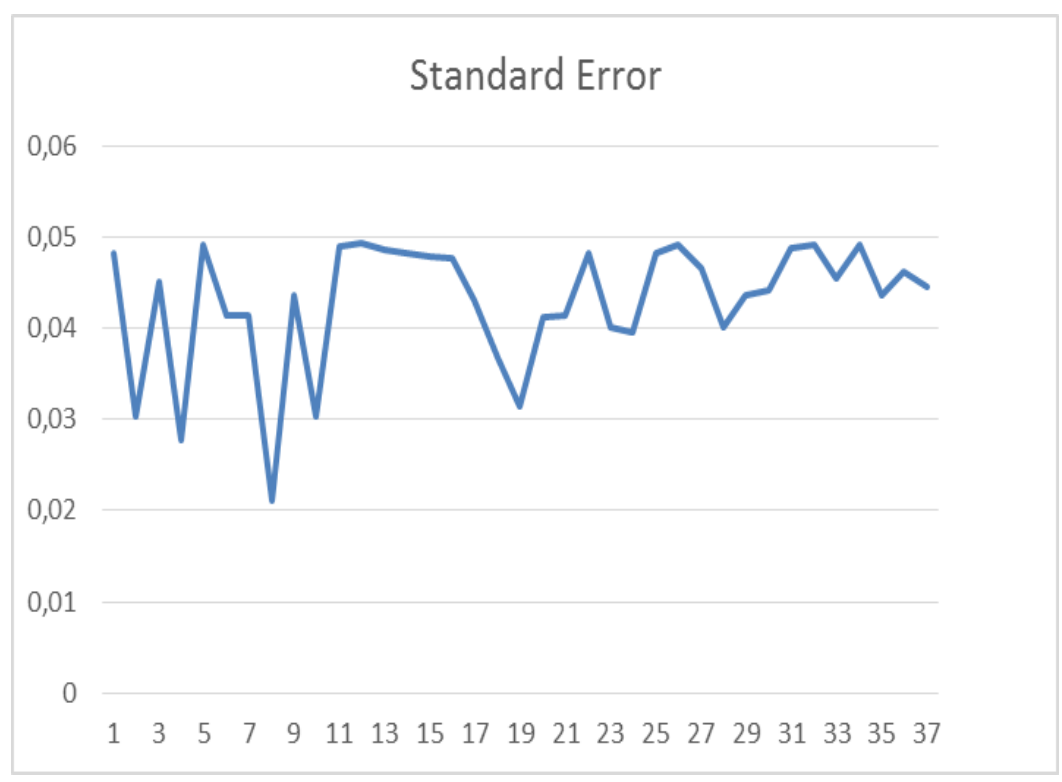

Figure 3. Standard Error values for each test item

The average standard error $1>0,043023>0$, primarily indicates the reliability of modified BRI. The modified BRI was then tested for its impact when introduced to learners of the same grades within the community not necessarily belonging to the same school. A test -comparing test (instead of test-retest using a single group) between two groups of learners undergoing studies in the same grade but from two schools was done. It was assumed, "the inventory was considered to have had construct reliability if the performances of both groups showed no significant differences." In other words, the concurrent validity was established. Statistically, a data set of more than 30 was considered large data. Hence the Z-test was used to validate the purpose of concurrent validity (presented in Table 4).

Table 4. Z-test value

\begin{tabular}{lll}
\hline z-Test:Two Sample for Means & & \\
\hline & Variable 1 & Variable 2 \\
Mean & 2.843771 & 2.747055 \\
Known Variance & 0.76088 & 0.37081 \\
Observations & 41 & 39 \\
Hypothesized Mean Difference & 0.577308 & \\
$Z$ & 0.577308 & \\
P(Z<=z) one-tail & 0.281866 & \\
z Critical one-tail & 1.644854 & \\
P(Z<=z) two-tail & 0.563732 & \\
z Critical two-tail & 1.959964 & \\
\hline
\end{tabular}


The observation showed $|\mathrm{z}|<\mathrm{z}$-Critical, and $\mathrm{p}>0.05$. This confirmed that the performances of both groups were similar (statistically), indicating that the modified BRI's measuring aspect was reliable to measure the purpose of measuring learners' knowledge and understanding in the area of periodic table, atom, molecule, and ionic bonds. The modified BRI was then tested for its internal consistency to pronounce it as a standard inventory. The internal consistency of the measuring tool was established using its Cronbach Alpha value. The following discussion is dedicated onto using MS- Excel to determine the Cronbach Alpha value. These could empower a researcher who does not have access to advanced software such as SPSS. The value of alpha as 0.87 is well accepted value. Hence, the modified BRI had its internal consistency and could be used as a reliable tool to measure the learners' knowledge and understanding in the periodic table, atom, molecule, and ionic bonding. Figure 4 presents a sample from the modified BRI.

1. One of the following do not represent a compound

$$
\begin{aligned}
& \text { (a) } \mathrm{O}-\mathrm{O} \\
& \text { (b) } \mathrm{C}-\mathrm{O} \\
& \text { (c) } \mathrm{N}-\mathrm{O} \\
& \text { (d) } \mathrm{H}-\mathrm{O}-\mathrm{H}
\end{aligned}
$$

2. Reason for my answer is

(a) It has three different atoms.

(b) It has two atoms from same element

(c) It has hydrogen

(d) It has nitrogen

3. One of the following represent an element
(a) $\mathrm{S}_{6}$
(b) $\mathrm{CO}_{2}$
(c) $\mathrm{CO}$
(d) None of the above

4. The reason for my answer is

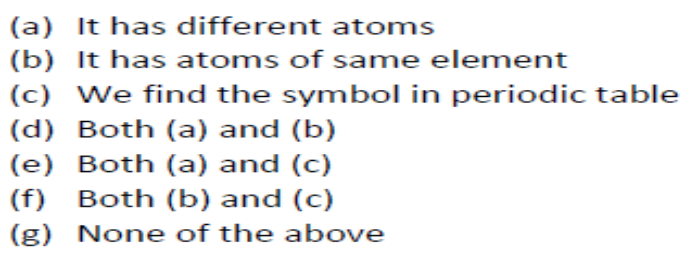

Figure 4. Snap Shot of the Modified BRI.

\section{Discussion}

Original BRI had ten test items relating to covalent bonding; hence, these ten test items were removed from the inventory before moderating the original BRI for the proposed study. There were 23 continuous test items in the original BRI without any groupings, of which ten test items were already removed. The original BRI included; the following: (i) Periodic Trends, (ii) Electrostatic interactions, (iii) The Octet rule, and (iv) Surface Features. The author was looking for a tool to study the learners' knowledge and understanding of the periodic table, atoms, molecules, and bonding (ionic only). A set of new test items were introduced to include the contents from the periodic table. This was conducted in consultation with local subject experts. These experts comprised high school chemistry teachers, science department heads, chemistry subject specialists, and university faculties from science education. Finally, the BRI was modified. Twenty-four new test items were added to the BRI. Consequently, the modified BRI constituted of the 37 test items in total and was grouped into four sections (A, B, C, and D).

Therefore, modified BRI was empowered to determine learners' state of learning about the periodic table, atoms, molecules, and ionic bonding. The author considered these forms fundamental component of high school chemistry courses and responsible for developing many alternate concepts carried by learners to their higher grades. The study 
prepared a standard, modified bonding representations inventory (Modified BRI). The objective of the study was to establish the validity and reliability of the modified BRI. Learning of humans occurs via three main interactive processes cognitive, experiential, and socio-cultural interactions (Jarvis, 2012). Every learning process involves the mind and intellect of a person. The author suggests that all human thought processes work in the same direction when common scientific content is handled by different individuals to uncover it and develop an understanding. In the process they either pick up the correct concept that needs to be developed in the mind or an alternate concept which hinders further learning of the appropriate scientific content. This fundamental is used here as a background to the need of developing a testing inventory in a content area of chemistry called the Periodic Table and Ionic Bonding.

This study provides good news for new academic research students who lack financial assistance. Those who need statistical software to analyse their data can use the MS-Excel spreadsheet without difficulty and achieve comparable data analysis accuracy of their data analysis. The MS-Excel spreadsheet is an integral part of MS- Office in any windows platform. On the other hand, academically used software such as SPSS is expensive and require training, which causes stress and delay for an individual researcher. The MS-Excel spreadsheet can save valuable time and provide freedom to work instead of becoming dependent on a third -party user for a data analysis report. This study confirmed that the modified BRI is a reliable tool for further use. The construct validity was established beyond doubt.

\section{CONCLUSION}

Modified BRI is a reliable tool for further use. The construct validity was established beyond doubt. The Microsoft Excel (MS-Excel) platform was used for standardizing the modified BRI because MS-Excel is available as a standard in MS-Office on the Windows platform. This paper presents a fact. That, a tool can be standardized by using MS-Excel without any complexity.

\section{ACKNOWLEDGMENT}

This was a part of a doctoral study conducted by the author. When one of the co supervisors of the study could not organize the data analysis laboratory because of their busy schedule, the main supervisor was advised to assess the use of MS -Excel for data analysis. The author wishes to acknowledge his main supervisor Dr. Rankhumise MP for the advice that allowed the study to proceed without hindrance. The Tshwane University of Technology paid the author's university fees and publishing costs for the research result.

\section{REFERENCES}

Beekman, A. T., Deeg, D. J. H., Van Limbeek, J., Braam, A. W., De Vries, M. Z., \& Van Tilburg, W. (1997). Brief communication.: criterion validity of the Center for Epidemiologic Studies Depression scale (CES-D): results from a community-based sample of older subjects in the Netherlands. Psychological Medicine, 27(1), 231-235. https://doi.org/10.1017/S0033291796003510.

Cronbach, L. J., \& Meehl, P. E. (1955). Construct validity in psychological tests. Psychological Bulletin, 52(4), 281. https://psycnet.apa.org/record/1956-03730-001.

Crooks, T. (2001). The validity of formative assessments. British Educational Research Association Annual Conference, University of Leeds, 13-15. 
http://www.leeds.ac.uk/educol/documents/00001862.doc.

Golafshani, N. (2003). Understanding reliability and validity in qualitative research. The Qualitative Report, 8(4), 597-607. https://core.ac.uk/download/pdf/51087041.pdf.

Hardesty, D. M., \& Bearden, W. O. (2004). The use of expert judges in scale development: Implications for improving face validity of measures of unobservable construc. Journal of Business Research, 57(2), 98-107. https://doi.org/10.1016/S01482963(01)00295-8.

Jarvis, P. (2012). Towards a comprehensive theory of human learning. Routledge.

Kane, M. T. (1982). A sampling model for validity. Applied Psychological Measurement, 6(2), 125-160. https://doi.org/10.1177\%2F014662168200600201.

Krause, S., Birk, J., Bauer, R., Jenkins, B., \& Pavelich, M. J. (2004). Development, testing, and application of a chemistry concept inventory. 34th Annual Frontiers in Education.

Luxford, C. J., \& Bretz, S. L. (2013). Moving beyond definitions: what student-generated models reveal about their understanding of covalent bonding and ionic bonding. Chemistry Education Research and Practice, 14(2), 214-222. https://doi.org/10.1039/C3RP20154F.

Nyachwaya, J. M., Mohamed, A. R., Roehrig, G. H., Wood, N. B., Kern, A. L., \& Schneider, J. L. (2011). The development of an open-ended drawing tool: an alternative diagnostic tool for assessing students' understanding of the particulate nature of matter. Chemistry Education Research and Practice, 12(2), 121-132. https://doi.org/10.1039/C1RP90017J.

Pellegrino, J. W., Chudowsky, N., \& Glaser, R. (2001). Knowing what students know: The science and design of educational assessment. National Academy Press.

Smith, K. C., \& Villarreal, S. (2015). Using animations in identifying general chemistry students' misconceptions and evaluating their knowledge transfer relating to particle position in physical changes. Chemistry Education Research and Practice, 16(2), 273-282. https://doi.org/10.1039/C4RP00229F.

Suat, Ü. N. A. L., Coştu, B., \& Alipaşa, A. Y. A. S. (2010). Secondary school students' misconceptions of covalent bonding. Journal of Turkish Science Education, 7(2), 329. http://www.tused.org/index.php/tused/article/view/508.

Taber, K. S. (2011). Models, molecules and misconceptions: a commentary on "secondary school students' misconceptions of covalent bonding. Journal of Turkish Science Education, 8(1), 3-18. http://www.tused.org/index.php/tused/article/view/342.

Tümay, H. (2016). Emergence, learning difficulties, and misconceptions in chemistry undergraduate students' conceptualizations of acid strength. Science \& Education, 25(1-2), 21-46. https://doi.org/10.1007/s11191-015-9799-x.

Vrabec, M., \& Prokša, M. (2016). Identifying misconceptions related to chemical bonding concepts in the Slovak school system using the bonding representations inventory as a diagnostic tool. Journal of Chemical Education, 93(8), 1364-1370. https://doi.org/10.1021/acs.jchemed.5b00953. 